UDC 811.113.6+811.161.1

\author{
Alexey Alyoshin \\ The Bonch-Bruevich Saint-Petersburg State University \\ of Telecommunications
}

Elena Zinovieva

St. Petersburg State University

\title{
A COMPARATIVE STUDY OF PHRASEOLOGICAL UNITS WITH THE COMPONENTS “COCK” AND "HEN" IN SWEDISH AND RUSSIAN
}

For citation: Alyoshin A., Zinovieva E. A Comparative study of phraseological units with the components "cock" and "hen" in Swedish and Russian. Scandinavian Philology, 2019, vol. 17, issue 2, pp. 284-297.

https://doi.org/10.21638/11701/spbu21.2019.206

The article discusses different types of evaluation demonstrated by comparative phraseological units with the components "cock" and "hen" in Swedish and Russian. Evaluation is one of the important linguistic categories associated with categories such as value and significance, which together make it possible to judge the mentality of a native speaker. The composition, semantics and functioning of phraseological units of the two languages are analysed. The material for the study is sourced from lexicographical works and the national corpora of the Russian and Swedish languages. It is concluded that in comparative phraseological units of the Swedish and Russian languages with the components "cock" and "hen" contain emotional rather than rational evaluativeness. The range of evaluative meanings of Swedish phraseological units is narrower than the corresponding spectrum of Russian units. Swedish units characterize only human behavior, and ethical evaluativeness in them prevails over aesthetic evaluativeness. Common to the two linguistic cultures are ideas about the cock as a pugnacious and cocky bird. Swedish does not use descriptions equivalent to the Russian like a plucked cock or dressing up like a cock. Swedish comparisons with the hen component, which were once gender-marked, are steadily moving toward gender neutrality, and the corresponding Russian units, representing a stupid and fussy woman, retain a vivid gender relation. The predominance of pejorative evaluation in two languages is probably due to the fact that chickens have always been available for close observation. Noting their appearance 
and behaviour, people never saw any positive qualities in them, probably aware of their utilitarian purpose.

Keywords: evaluativeness, comparative phraseological unit, meaning, stereotypical representation, semantics.

\section{INTRODUCTION}

A distinctive feature of modern linguistic research in general and in the field of phraseology, in particular, is its interdisciplinary nature. It draws upon findings from semantics, cognitive linguistics, language and culture studies, psycholinguistics and sociolinguistics. The general theory of categorization of real-world objects and language units, which is the basis of various research avenues, plays a significant part in this. Evaluativeness is one of the important linguistic categories associated with categories such as value and significance, which together make it possible to assess the mentality of the nation speaking the language. In the academic literature, the terms "evaluativeness" and "evaluation" are often used as synonyms. The evaluation category as a whole is defined in the "Stylistic Encyclopedic Dictionary" as "a set of multilevel language units united by evaluative semantics and expressing a positive or negative attitude of the author to the content of speech" [Stylistic Encyclopedic Dictionary...]. In general terms, evaluation "implies the value aspect of the meaning of linguistic expressions and is characterized by a special structure - a modal framework that is superimposed on the statement and does not coincide with its logical-semantic or syntactic construction. The elements of the evaluated modal frame are the subject and the object connected by the evaluative predicate. The subject of evaluation (explicit or implicit) is the person or society from the point of view of which the assessment is given, the object of evaluation is the person, object, event or state of things to which the assessment relates. In addition, the modal frame includes (mostly implicitly) a rating scale and stereotypes that the assessment is oriented towards in social representations of communicants" [Stylistic Encyclopedic Dictionary...]. In relation to linguistic units, it seems to us more appropriate to use the term "evaluativeness", since the term "evaluation" is more applicable, in our opinion, to the logical-conceptual field of research. Currently, the application of the evaluation category to phraseological units has been studied in a number of dissertations (see, for example, [Yakhina, 2008; 
Timirgaleeva, 2010]), however, only a small number of such studies involved a comparative analysis of two or more languages. There is a clear lack of comparative Swedish-Russian studies.

The purpose of this article is to compare Swedish and Russian phraseological units with the components "cock" and "hen" in terms of their evaluativeness. The analysis focused on the semantics, types of evaluations expressed in comparisons and verbalised stereotypical representations in the two cultures. The study drew on Swedish and Russian lexicographic sources [SS; SAOB; Ogoltsev, 2001; Mokienko, 2003] and the national corpora of the two languages [www.ruscorpora.ru - Russian National Corpus [RNC], [RNC; KD].

\section{SWEDISH COMPARATIVE PHRASEOLOGICAL UNITS WITH THE COMPONENTS “COCK” AND "HEN"}

In modern Swedish, cock is denoted by the word tupp, originally used to refer to the bird's bright crest. The paultry's behaviour has been observed by people for centuries; since ancient times the cock has been a forerunner of morning light, as well as the symbol of a warrior. These ideas are reflected in Old Norse mythology, in which three cocks were to wake up the gods, the underworld and the giants on the day of the last battle [Hellquist, 2005].

However, in common idiom, a different vision of the cock took hold in the Swedish culture - its militancy received an ironic coloring in the Swedish linguistic consciousness. Swedish folklore researcher M. Hellquist makes comparisons such as stridlysten som en tupp 'pugnacious like a cock', indicating that this characteristic is by no means a praise for humans, and vara som två tuppar på en sten 'to be like two cocks on one stone', which implies the inability of people to get along together [Hellquist, 2005, s. 200].

The most frequent Swedish comparative phraseology with the "cock" component is stolt som en tupp 'proud as a cock. The Swedish Phraseological Dictionary defines its meaning simply as "being very proud" [SS, s. 1245]. But the numerous contexts of the use of this unit tell us that human behaviour, characterized in this way, is disapproved by society: Hela kvällen gick Moderat omkring, stolt som en tupp, oupphörligt återkommande till episoden med verkmästarn. 'All evening the Moderat walked proud as a cock, constantly returning to the episode with the foreman' 
[KD]; Det första hon säger när hon slår upp ögonen är att hon vill ha sin peng. Det fick hon självklart och stolt som en tupp lägger hon den $i$ sin sparbössa. 'The first thing she said, opening her eyes, was that she wanted to get her pocket money. She was given it, of course, and, proud as a cock, she put it in her piggy bank' [KD]. As can be seen from the above examples, this comparison is common both in classical fiction and in modern contexts found on the Internet. It is noteworthy that in contemporary Swedish it can be used not only in relation to a man, but also to a woman.

The proud and arrogant behaviour of the cock was reflected in two other Swedish comparisons, gå omkring som en tupp 'to walk around like a cock' and fjädra sig som en tupp 'to open feathers like a cock': Utmanövrerad och besegrad äskar hans personlig res märkligt npe og grm-

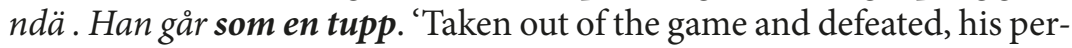
son still, surprisingly, demands respect in the congregation. He paces like a cock' [KD]; Men nu stod han där som en tupp framför speglarna och fjädrade sig, medan de andra fäntrattarna i gymet stod och beundrade honom, mer eller mindre öppet. 'But now he stood there like a cock in front of the mirrors and opened his feathers, while the other fools in the hall stood and admired him, more or less openly' [KD].

Thus, all the units considered characterize the behaviour of a person, mainly of a man, and all comparative phraseological units with a cock component in Swedish have an inherent pejorative connotation.

The hen in Swedish is indicated by the word höna, originating from the common German root with the meaning 'female cock'. M. Hellquist points out that since ancient times, the hen was considered in the Swedish language as a stupid, limited and enthusiastic bird, and from the $18^{\text {th }}$ century you can trace the regular attribution of these qualities to women, manifested in comparisons such as springa som yra höns 'running like crazy hens', gå som en äggsjuk höna 'walk like a hen who wants to lay eggs', and also in units with internal comparative semantics - ha hönsminne 'have a hen memory' and ha hönshjärna 'have a hen brain' [Hellquist, 2005, s. 192]. However, an analysis of the use of the above comparative phraseological units, both in classical literature and in modern use, allows us to conclude that these units are moving toward gender neutrality: Men han betedde sig $i$ allt som en äggsjuk höna och till och med Fredrik måste småle. "But he behaved in everything like a hen who wants to lay eggs, and even Fredrik could not help grinning' [KD]; Den som har sett riktigt krig vet att det handlar om att sitta som en äggsjuk höna och vänta. 'Anyone 
who has seen a real war knows that you need to sit there like a hen who wants to lay eggs and wait' [KD]. As follows from the above examples, the comparison in question can be used not only in relation to a man, but also to a woman, as well as in a generalized neutral way. In these examples, the comparison is accompanied by the replacement of the base $g a$ (walk) with bete sig (behave) and sitta (sit).

Comparison of springa som yra höns 'running like crazy hens' can also be considered long used as gender-unmarked: Det är tjurauktion, tjuren kommer lös och hela skaran av spekulanter springer som yra höns, tills lagårdspigan lyckas locka in honom att honom hans välkända hink med mjölröra. 'A bull auction, a bull is released, and the whole crowd of bidders runs like crazy hens until the milkmaid manages to lure it into the stable, showing it a familiar bucket of food' [KD]; Ingen vinner på en stressad organization och vi vill definitivt inte ha folk som springer omkring som yra höns. 'Nobody needs stress in the organization, and we don't need those who run like crazy hens' [KD]. It should be noted that the word höns is a collective designation of hens and a cock, which in itself entails greater gender neutrality than höna. M. Bohlin points out that the comparison of springa som yra höns have over time replaced the older unit flyga runt som yra hönor 'fly like crazy hens', where the word höna is used in the model [Bohlin, 2010, s. 19].

M. Hellquist also provides comparisons such as sitta som en höna på en käpp i blåsväder 'sitting like a hen on a pole in bad weather' about a person who is in an unpleasant situation, springa som hönan med snöret 'running like a hen with a lace' and se ut som man skulle ha stulit höns 'looks like he has been stealing hens' - about a bald man [Hellquist, 2005, s. 193]. The last two units require cultural commentary. The image of the lace with which the hen runs refers to the stereotypical idea of the stupidity of a bird that cannot distinguish between a lace and a worm [SAOB]. According to legend, a person who stole hens became bald. However, we were not able to find contexts for the use of such units, which allows us to classify them as obsolete.

Thus, the hen in Swedish comparative phraseological units has become the standard of negatively assessed behaviour due to it being considered a naturally stupid bird. 


\section{RUSSIAN COMPARATIVE PHRASEOLOGICAL UNITS WITH THE COMPONENTS “COCK” AND "HEN"}

The nomination of a cock in the Russian language is etymologically related to its singing. With its singing, the cock drives away the night's darkness, announces the beginning of a new day. The cock in Slavic culture is "a prophetic bird endowed with fiery, solar, and male sexual and marriage symbolism and the symbolism of fertility, the ability to withstand evil spirits and at the same time with demonic properties" [Slavic Antiquities..., 2009, p. 28].

Russian comparative phraseological units, too, reflect peoples' ideas about the behaviour and appearance of the birds based on centuries of observation. The cock acts as the prototype of a pugnacious man. This image materializes in a Russian speaker's mind when they hear the expression $\boldsymbol{\kappa} \boldsymbol{a} \boldsymbol{\kappa} \boldsymbol{n} \boldsymbol{e m \boldsymbol { x }}$ ' like a cock'; cf. also the expanded expression $\kappa a \kappa$ молодой nетух 'like a young cock'. The zoonym is used in this case also with the basis for comparison: задиристый, драчливый как петух и налетать, наскакивать на кого-либо как петух 'cocky, pugnacious like a cock and swoop down, jump at someone like a cock'. Examples include: Мать рассказывает, ты драться любишь. "Он у меня, говорит, драчливый как петух». - Жухрай рассмеялся одобрительно. - Драться вообще не вредно, только надо знать, кого бить и за что бumb. Mother tells me you like to fight. 'She says he is as pugnacious as a cock," Zhukhrai laughed approvingly. Fighting is not a bad thing, you just need to know whom to hit and what for' [RNC]; Классическое разделение ролей: Мишин как петух наскакивал на Глушко, а Королев выступал в роли примиряющего apбumpa. 'Classical separation of roles: Mishin jumped at Glushko like a cock, and Korolev acted as a conciliating arbitrator' [RNC]; Когдa Карабаш сердился, его глаза делались узкими и желваки на скулах твердели, как литые. Он говорил негромко, зато Гохберг кричал и наскакивал на Смирнова, как петух. 'When Karabash was angry, his eyes became narrow and the nodules on the cheekbones hardened like molten ones. He spoke quietly, but Gokhberg shouted and jumped at Smirnov like a cock' [RNC]. There is a stereotypical frame in the Russian linguistic consciousness of a fight between two cocks or of one of the traditional folk amusements - a cockfight; cf. the comparative phraseological unit сиепиться (набрасьваться, налетать) друг 
на друга как петухи (два петуха) 'picking a fight with, pounce or swoop on each other like cocks (two cocks)' - about men fighting or fervently quarreling. The axiological vector aimed at a person is that of ironic evaluation.

The cock also serves as a metaphor for a person behaving arrogantly, importantly, exaggerating their own significance: заносиивьй, важный, спесивый (надутый) как петух (arrogant, important, and prancing like a cock). This phraseology expresses disapproval. For example: Я испьтал тогда жестокую обиду за Франиию и за франиузов, обиду за великую франиузскую культуру, за Дидро и Вольтера, Гюго и Стендаля, за Золя и Коро, за Пастора и Делакруа, за всех великих франиузов, которых никто из нас не отделял от русских. Они казались нам такими же родными, как Пушкин, Толстой, Чехов. Они были жестоко унижены политическими маклаками Франции и их представителем - надутым, какпетух, генералом д’Ансельмом. Я представлял себе, с каким холодным презрением Стендаль или Гюго приказали бы расстрелять этого генерала за его трусливую подлость. 'I experienced then great empathy for France and for the French, for the great French culture, for Didro and Voltaire, Hugo and Stendhal, for Zola and Corot, for Pastor and Delacroix, for all the great Frenchmen whom none of us separated from Russian culture. They seemed to us as dear as Pushkin, Tolstoy, and Chekhov. They were brutally humiliated by the political dealers of France and their representative - prancing like a cock, General d'Anselm. I imagined with what cold contempt Stendhal or Hugo would have ordered this general to be shot for his cowardly meanness' [RNC].

The phraseological unit одеться (нарядиться, вырядиться) как nemyx 'to dress up like a cock' is used to refer to a person who wears clothes of inappropriately bright, motley colours. This expression implies a negative connotation. For example: Наши дети в этом отношении слепь: они видят только то, что надето, нарисовано, раскрашено. Можно объяснить дочке (и сыну, если он склонен рядиться как nетух), что с таким макияжем она прельстит только совершенно примитивных парней, что ее запросто можно принять за девочку по выззову. 'Our children are blind in this respect: they see only what the person is wearing, motifs and colours. You can explain to your daughter (and son, if he is inclined to dress up like a cock) that with such a make-up, she will attract only completely primitive guys that she can easily be mistaken 
for a call girl' [RNC]; Тщзательно избегайте кричащей одежды. Если будете одеваться как петух, то вас примут за заурядного негра, а не за вождя революиии. 'Avoid flashy clothing carefully. If you dress like a cock, then you will be taken for an ordinary black man, and not for the leader of the revolution' [RNC]. Stereotypically, a person dressed in this way is considered to be stupid, uncivilized, and with a bad taste. A woman dressed in this way is viewed as a woman of easy virtue.

The expression махать руками как петух крыльями 'wave one's hands like a cock waves its wings' is used to refer to a man who makes abrupt and expansive movements with his hands. For example: $-Э \breve{u}$, кто тут? Эй! - закричал возница и захлопал руками, как петух крыльями. - Эй, доктора привез! 'Hey, someone here? Hey! The driver cried out and flapped his hands like a cock flapping its wings. Hey, I brought the doctor!' [RNC].

A scanty, miserable-looking man is characterized by the idiom $\boldsymbol{\kappa} \boldsymbol{a \kappa}$ ощиипанный петух 'like a plucked cock'. For example: Предсказания Роберта Блюма исполнились:недостало иемента, чтобы спаять им со стеною иеркви камень, оставленный без заливки подневольным каменшиком старой империи. Старик Райнер, разбитый в своих упования $x$, сидел один, гнулся $и$, как ощипанный петух, прятал свой обдерганный хвост. 'Robert Blum's predictions have come true: there wasn't enough cement to glue a stone left without filling by the bonded bricklayer of the old empire to the wall of the church. Old Reiner, broken in his hopes, sat alone, bent over and, like a plucked cock, hid his worn tail' [RNC]. The unit implies ironic evaluativeness.

Thus, the Russian comparative phraseological units with the component "cock" are distinguished by their emotional value. Two phraseological units are pejorative (заносчивый как петух 'arrogant like a cock' - ethical evaluation and одеться как петух 'dressing up like a cock' - aesthetic evaluation). They reflect disapproval. The rest are neutral, but may differ in usage - about men (задиристый как петух, как молодой петух, налетать как петух, сиепиться как петухи 'pugnacious as a cock, like a young cock, jump at someone like a cock, fight like cocks' and ironic evaluativeness.

In Slavic culture, the hen is a poultry endowed with marital and erotic symbols and demonic features. The ritual use of the hen is noted at turning points in the calendar, agricultural and life cycles, as well as in healing magic and fortune telling [Slavic Antiquities..., 2009, p. 60-61]. 
Russian comparative phraseological units with the component "hen" also reflect people's observations of the behaviour and appearance of the bird. There is some symmetry, mirroring in comparisons using the words cock and hen. The comparative phrase как курица 'like a hen' is used by default only in relation to a woman in the meaning 'about a stupid, fussy, noisy woman'. For example: Любовнииа имела безработного мужа, к томуже была глупа как курииа. 'The lover had an unemployed husband, besides she was as stupid as a hen' [RNC]. In the above context, the seme of stupidity comes to the fore. The comparative phraseological unit is dismissive. The comparison как ощипанная курица 'like a plucked hen', like a similar comparison with a cock, characterizes a miserable, skinny, awkward looking person: - Нукакой же я человек? Утром встаю взъерошенная, как овия; на работу бегу голодная, как шакал... вылезу из трамвая ощипанная, как курица. 'Well, what kind of person am I? In the morning I get up disheveled like a sheep; I'm hungry for work, like a jackal ... I'll get out of a tram plucked like a hen' [RNC]. In the above context, thanks to the interchanging of the components of the phraseological unit, irony is added to contempt. The comparative expression, which has not yet entered dictionaries, хлопать руками как курииа крыльями 'to clap one's hands as a hen flaps its wings' is synonymous with the abovementioned cock comparison; cf.: Дима заваливался на капот джипа, закрьв лицо руками, Коля приседал и хлопал руками, как курииа крьльями. 'Dima fell on the hood of the jeep, covering his face with his hands, Kolya squatted and clapped his hands as a hen flaps its wings' [RNC].

According to the RNC, the most frequent phrase is носиться с кем, с чем как курииа сяйом 'to run with someone or something like a hen with its egg' - 'about a fussy person uselessly bustling over a petty thing. For example: Я чувствовала себя безумно счастливой и в то же время жутко боялась. Еще не отдавая себе отчет в собственных переживаниях, не формулируя для себя происходящего, я носилась с тобой, как курица сяйцо, стараясь уберечь, поддержать, направить. 'I felt incredibly happy and at the same time terribly afraid. Not yet aware of what I felt, not being able to formulate to myself what was happening, I fussed over you like a hen over its egg, trying to protect, support, and direct' [RNC]. The comparison is dismissive or ironic. 
The Russian phrase как мокрая курииа 'like a wet hen' is used in two meanings: 'about a miserable, trembling, depressed, dejected and sad person' and 'about a sluggish, passive, inert and helpless person'. In both cases, the unit is distinguished by contemptuous attitude. For example: Холодный ветер с сухой пылью ударил в него. Как мокрая курица с желтыми тоскливыми глазами, Сапожков брел по бульвару. 'A cold wind with dry dust hit him. Like a wet hen with yellow dreary eyes, Sapozhkov wandered along the boulevard' [RNC]; Попов вновь встает, и, обрашаясь к свидетелю, старается добиться от него более толкового разбяснения - почему он арестовал нас, а не полиимейстер. Но этого ответа получить нельзя было, и свидетель, как мокрая курииа, осмеянный, садится на свое место. 'Popov gets up again, and, turning to the witness, tries to get a more sensible explanation from him - why he arrested us, and not the police chief. But this answer could not be obtained, and the witness, like a wet hen, ridiculed, sits in his place' [RNC].

The fixed comparison зарезать кого как курииу 'to slay someone like a hen' is used to refer to someone who has ruthlessly slain someone; it is often used as a threat and has a pronounced disapproving evaluativeness. The imagery is based on the stereotypical idea of killing a chicken for consumption in a traditional peasant setting. But the utilitarian assessment of direct prototypical action turns into an ethical assessment in relation to violence against a person.

The word hen is often used when it comes to poor handwriting. The ironic or joking expression писать как курииа лапой 'to write with a hen's foot': Диктант по клеточкам для меня открытие... мой леворукий пишет как курииа лапой! Да и посмотрев на тесть прошлого года, возникает вопрос... зачем им учиться в первом классе? Надо сразу в среднюю школу!!!! 'A dictation in a squared notebook is a revelation to me... my left-handed boy has a handwriting like chicken scratch! Looking at the tests of last year, the question arises ... why should they study in the first year? They should go to middle school right away!!!! [RNC]. The phrase y кого-то почерк как у курицьь 'someone's handwriting is like that of a hen)' - 'about someone's bad, illegible, and hastily careless handwriting' can be not only ironic, but also disapproving: И какие вы странные! Учитель чистописания, а почерк как у курицы! Как же вы учите писать, если сами плохо numeme? - Гм!... 'And you are so strange! A teacher of calligraphy with 
a handwriting is like chicken scratch! How do you teach writing if you yourself write poorly? - Um!..' [RNC].

Thus, Russian comparative phraseological units with the component “курица", as well as the units analyzed above with the component "петух" project an emotional evaluation. The ethical evaluation prevails over the aesthetic with the exception of the comparison $\kappa a \kappa$ ощипанная курица (as a plucked hen). On the whole, the connotation is pejorative; the range of meanings is wider than that of phraseological units with the component "петух": there are disapproving, contemptuous, and dismissive evaluations. However, there is a "mirroring" of some comparative phraseological units with the words "петух" and “курица" in Russian. In addition, in the plural form of the noun куриць loses its gender identity and denotes a collection of birds, both males and females, cf. such phraseological units as nеребить, передушить как кур 'to kill, strangle like hens' - 'to kill in an easy and simple way, using your superior power or because of the victim's inability to resist,' as well as ironic phraseological unit руки дрожат (трясутся) у кого-то будто кур воровал 'someone's hands are shaking as if they had been stealing hens' - 'about a person in a state of intense excitement, anxiety, or fear.'

\section{RESULTS}

The study found that Swedish and Russian comparative phraseological units with the components cock and hen contain exclusively emotional, not rational evaluativeness. The range of particular evaluative meanings of Swedish phraseological units is narrower than the corresponding spectrum of Russian units. It contains connotations of disapproval, condemnation and irony. Swedish units characterize only human behaviour whose ethical evaluation completely prevails over aesthetic assessment. Common to the two linguistic cultures are ideas about the cock as a pugnacious and cocky bird. Swedish does not use descriptions equivalent to the Russian like a plucked cock or dressing up like a cock. Swedish and Russian comparative phraseological units with the component "hen" display significant differences. While Swedish comparisons with this component, which were once gender-labeled, are steadily moving towards gender neutrality, the corresponding Russian units, describing a stupid and fussy woman, retain a strong gender relation. Such Russian 
units as to slay like a hen, like a wet hen and write with a hen's foot do not find correspondence in the Swedish language. The meaning of the Swedish gå omkring som en äggsjuk höna and the Russian носиться как курииа с яйцом is somewhat different. The Russian unit, unlike the Swedish one, involves preoccupation with a minor thing.

The predominance of pejorative evaluation in two languages is probably due to the fact that chickens have always been available for close observation. Noting their appearance and behaviour, people never saw any positive qualities in them, probably aware of their utilitarian purpose to produce food (eggs) or to serve as food.

\section{REFERENCES}

Mokienko V.M. Dictionary of comparisons of the Russian language: 11,000 units. St. Petersburg: Norint Publ., 2003. (In Russian)

Ogoltsev V.M. Dictionary of Fixed Comparisons of the Russian Language: (synonym-antonymic). Moscow: Russian Dictionaries LLC: Astrel Publ. LLC: AST Publ. LLC, 2001. (In Russian)

Slavic Antiquities. Ethnolinguistic Dictionary. Vol. 4. Moscow: International Relations Publ., 2009. (In Russian)

Stylistic Encyclopedic Dictionary of the Russian Language. Moscow: Flint, Nauka Publ., 2003. Available at: http://rus-yaz.niv.ru/doc/stylistic-dictionary/index. htm (accessed: 15.05.2019). (In Russian)

Timirgaleeva E. R. The evaluative nature of phraseological units with components of vertical space in Russian, English and French. Diss. ... cand. philol. sciences. Yekaterinburg, 2010. 211 p. (In Russian)

Iakhina A.M. Evaluation as a Component of the Meaning of Phraseological Units in Russian, English and Tatar Languages. Diss. ... cand. philol. sciences. Kazan, 2008. 226 p. (In Russian)

Bohlin M. Ungtuppar och hönshjärnor - en studie över hönsmetaforer för mänskligt utseende eller beteende. Göteborg, 2010. $30 \mathrm{~s}$.

Hellquist M. Göra en pudel och sova räv. Stockholm: Atlantis Publ., 2005. 245 s.

\section{ABBREVIATIONS AND INTERNET RESOURCES}

KD - Korp databas. Available at: https://spraakbanken.gu.se/korp (accessed: 22.08.2019)

RNC - Russian National Corpus. Available at: http://www.ruscorpora.ru/ (accessed: 22.08.2019).

SAOB - Svenska Akademiens Ordbok. Available at: https://www.saob.se/ (accessed: 22.08.2019). 
SS - Svenskt Språkbruk. Ordbok över konstruktioner och fraser. Stockholm: Norstedts, 2003.

Алексей Алёшин

Санкт-Петербургский государственньй университет телекоммуникаций им. проф. М.А.Бонч-Бруевича

Елена Зиновьева

Санкт-Петербургский государственный университет

\section{ОЦЕНОЧНОСТЬ КОМПАРАТИВНЫХ ФРАЗЕОЛОГИЗМОВ ШВЕДСКОГО ЯЗЫКА С КОМПОНЕНТАМИ ПЕТУХ" И "КУРИЦА" (В СОПОСТАВЛЕНИИ С РУССКИМ ЯЗЫКОМ)}

Для цитирования: Alyoshin A., Zinovieva E. A Comparative study of phraseological units with the components "cock" and "hen" in Swedish and Russian // Скандинавская филология. 2019. Т. 17. Вып. 2. С. 284-297.

https://doi.org/10.21638/11701/spbu21.2019.206

В статье рассматриваются типы оценочности шведских компаративных фразеологизмов с компонентами «петух» и «курица» в сопоставлении с русским языком. Оценочность является одной из важных языковых категорий, связанных с такими категориями, как ценностность и значимость, позволяющими в совокупности судить о менталитете народа - носителя языка. Анализируются состав, семантика и функционирование фразеологических единиц двух языков. В качестве источников материала служат лексикографические произведения, а также материалы национальных корпусов русского и шведского языков. В результате исследования делаются выводы о том, что в компаративных фразеологизмах шведского и русского языков с эталонами петух и курица присутствует исключительно эмоциональная, а не рациональная оценочность. Спектр частнооценочных значений шведских фразеологизмов у́же соответствующего спектра русских единиц. Шведские единицы характеризуют только поведение человека, и этическая оценочность в них полностью превалирует над эстетической. Общими для двух лингвокультур являются представления о петухе как о драчливой и задиристой птице. Лакунарным относительно шведского языка является описание внешности с помощью русских сравнений как ощипанный петух, рядиться как петух. Шведские сравнения с компонентом курица, являвшиеся когда-то гендерно маркированными, неуклонно движутся в сторону гендерной нейтральности, а соответствующие русские единицы, обозначающие глупую и суетливую женщину, сохраняют яркую гендерную отнесенность. Преобладание пейоративной оценки в двух языках можно мотивировать тем, что домашние птицы всегда были доступны для близкого наблюдения, поэтому человек отмечал особенности их внешнего вида, поведения, но при этом не видел в них положительных качеств, вероятно, осознавая их утилитарное назначение.

Ключевые слова: оценочность, компаративный фразеологизм, значение, стереотипное представление, семантика. 


\section{Alexey Alyoshin}

$\mathrm{PhD}$ in Philology, Associate Professor,

The Bonch-Bruevich St. Petersburg State University of Telecommunications, 22, pr. Bolshevikov, 193232, St. Petersburg, Russia

E-mail: alexis001@mail.ru

\section{Алёшин Алексей Сергеевич}

кандидат филологических наук, доцент,

Санкт-Петербургский государственный университет телекоммуникаций им. проф. М. А. Бонч-Бруевича,

Россия, 193232, Санкт-Петербург, пр. Большевиков, 22

E-mail: cafedra24@mail.ru

\section{Elena Zinovieva}

Doctor of Philology, Professor,

St. Petersburg State University,

7-9, Universitetskaya nab., 199034, St. Petersburg, Russia

E-mail: e.i.zinovieva@spbu.ru

\section{Зиновьева Елена Иннокентьевна}

доктор филологических наук, профессор,

Санкт-Петербургский государственный университет,

Россия, 199034, Санкт-Петербург, Университетская наб., 7-9

E-mail: e.i.zinovieva@spbu.ru 